American Journal of Agricultural and Biological Sciences 6 (1): 62-68, 2011

ISSN 1557-4989

(C) 2010 Science Publications

\title{
Effect of an Insecticide Abamectin on Some Biochemical Characteristics of Tilapia Fish (Oreochromis Niloticus)
}

\author{
Mohammed A. Al-Kahtani \\ Department of Biological Sciences, College of Science, King Faisal University, \\ 31982- Al-Hassa. P.O. Box: Saudi Arabia
}

\begin{abstract}
Problem statement: Presence of pesticide in streams and lakes is largely due to the runoff from agricultural fields. Pesticides are not highly selective but are generally toxic to many macrophytes, non-target organisms such as fish. Fish, generally accumulate contaminants from aquatic environments and have been largely used in food safety studies. Approach: The toxic effect of the insecticide abamectin on oxygen consumption and some biochemical characteristics (total protein, carbohydrate and cholesterol in liver, muscle, kidney and gills) of the tilapia fish (Oreochromis niloticus) were estimated. Results: The data shows that the rate of oxygen consumption was declined during all the exposure periods. On the other hand, all biochemical's parameters were found to be decreased in all tissues on comparison with control. Conclusion: The results indicated the toxic nature of the insecticide abamectin.
\end{abstract}

Key words: Aabamectin; biochemical's parameters; tilapia fish; fish organs; toxicity

\section{INTRODUCTION}

With rapid industrialization and increase in human population, the pollution of water bodies has become a universal phenomenon in the present day world (Bela and Prasad, 2008). The important sources of water pollution are industrial effluent, domestic, sewage, drainage and pesticides, which pollute the river and major water sources (Maruthanayagam and Sharmila, 2004). Pesticides and related chemicals destroy the delicate balance between species that characterizes a functioning ecosystem (Khan and Francis, 2005). Presence of pesticide in streams and lakes is largely due to the runoff from agricultural fields and outfall from pesticide manufacturing factories (Anandkumar, 1988). Pesticides are not highly selective but are generally toxic to many macrophytes, non-target organisms such as fish (Ayoola, 2008; Franklin et al. 2010).

Fish is highly nutritious, easily digestible and much sought after food. Nutritional value of fish depends on their biochemical composition, which is affected by the water pollution (Prado et al., 2009). Alterations in biochemical components as response to environmental stress are authenticated by many authors. Tilak et al. (2001) studied the toxicity and effect of chloropyriphos to the freshwater fish Labeo rohita (Hamilton); Alkhail et al. (2004) studied the toxicity and sub lethal effects on brain AChE and gill ATPases activity of tilapia fish, Oreochromis niloticus. Arockia and Mitton (2006) investigated the effect of carbamate pesticide lannate (methomy1) on the biochemical components of the freshwater cichlid Oreochromis mossambicus (Peters); Venkateswara (2006) studied the toxic effects of novel organophosphorus insecticide (RPR-V) on certain biochemical parameters of euryhaline Wsh, Oreochromis mossambicus.; Shereena et al. (2009) studied the effect of an organo phosphorous pesticides (Dimethoate) on oxygen consumption of the fish Tilapia Mossambica.; Impact of Cypermethrin and Ekalux on respiratory and some biochemical activities of a fresh water fish, Tilapia mossambica was studied by Logaswamy and Remia (2009); recently Patnaik (2010) studied the biochemical alterations Induced by Sevin in Clarias batrachus.

Saudi Arabia is the largest date producer in the world. Abamectin is used in Saudi Arabia to control motile mites and some other insects (Kamel et al., 2007; Fathi and Al-Fredan, 2007). Abamectin can runoff from the sites of application and becomes an aquatic pollutant (Tatjana and Nevenka, 2006). In addition Fish, generally accumulate contaminants from aquatic environmentsand have been largely used in food safety studies. The aim of this study was to identify the toxicity of abamectin on oxygen consumption and some physiological activities of tilapia fish (Oreochromis niloticus) 
Am. J. Agri. \& Biol. Sci., 6 (1): 62-68, 2011

\section{MATERIALS AND METHODS}

Abamectin (1.8\% EC) Arab Industrial Company, Dammam, Saudi Arabia was used in this study. The main structural characteristics and structural formula of Abamectin were presented in (Table 1 and Fig. 1).

For the present study, Fresh water fish Tilapia (Oreochromis niloticus) were collected from AlKhadoud spring channel and experiment was conducted in the laboratory at Department of Biological Sciences, College of Sciences, King Faisal University during summer 2009. Table 2 shows the means values of the physico-chemical characteristics of Al-Khadoud channel water (Fathi and Al-Kahtani, 2009). The fishes were acclimated to the laboratory temperature $(23 \pm 0.5)$ in large glass aquarium. The fish were fed twice daily with $38 \%$ protein commercial fish food (CP-Pet; Pokphand Animal Food Co. Ltd., Bangkok, Thailand). The period of acclimation lasted for 2 weeks. Batches of 10 healthy fishes were exposed to different concentrations of insecticide abamectin to calculate the medium lethal concentration $\mathrm{LC}_{50}$ value using probit analysis method (Finney, 1971).

The fishes (Four groups) were exposed to the sub lethal concentration $\left(20 \mu \mathrm{g} \mathrm{L}^{-1}\right)$ of abamectin for 24,48 72 and $96 \mathrm{~h}$ respectively. Another group was maintained as control. At the end of each exposure period, fishes were sacrificed and tissues such as liver, gill, muscle and kidney were dissected and removed. The tissues $(10 \mathrm{mg})$ were homogenized in $80 \%$ methanol, centrifuged at $3500 \mathrm{rpm}$ for $15 \mathrm{~min}$ and the clear supernatant was used for the analysis of total proteins, carbohydrates and cholesterol. Total Protein concentration was estimated by the method of Lowry et al. (1951). Total carbohydrate in the tissue was estimated by the method described by Hedge and Horfreiter (1962). Cholesterol was estimated based on enzymatic method using cholesterol esterase, cholesterol oxidase and peroxides (Richmond, 1973). Changes in the rate of oxygen consumption of the fishes were evaluated at different exposure periods. The rate of oxygen consumption was estimated by Winkler's method (Welsh and Smith, 1960), the results were in $\mathrm{ml} \mathrm{g}^{-1} \mathrm{~h}^{-1}$. Results were tested by one-way Analysis Of Variance (ANOVA). ANOVA effects and treatments differences were considered significant when $p<0.05$.
Table 1: The main structural characteristics of abamectin

\begin{tabular}{|c|c|}
\hline Common name & $\begin{array}{l}\text { abamectin (BSI, draft E-ISO, } \\
\text { ANSI); abamectine (f) draft F-ISO }\end{array}$ \\
\hline Chemical name: & Avermectin B1 \\
\hline Appearance: & $\begin{array}{l}\text { Abamectin is a colorless to yellowish } \\
\text { crystalline powder }\end{array}$ \\
\hline Molecular weight: & 873.11 \\
\hline Water solubility: & Insoluble \\
\hline Solubility in other solvents: & $\begin{array}{l}\text { Vs in acetone, methanol, toluene, } \\
\text { chloroform and ethanol. }\end{array}$ \\
\hline Melting point: & $150-155^{\circ} \mathrm{C}$ \\
\hline Vapor pressure: & Negligible \\
\hline Composition & $\begin{array}{l}\text { A mixture containing }{ }^{3} 80 \% \text { avermectin } \\
\mathrm{B}_{1 \mathrm{a}}(\mathrm{i}) \text { and } £ 20 \% \text { avermectin } \mathrm{B}_{1 \mathrm{~b}} \text { (ii). }\end{array}$ \\
\hline Chemical class: & Insecticide/miticide \\
\hline Acute toxicity: & $\begin{array}{l}\text { Abamectin is highly toxic to insects and } \\
\text { may be highly toxic to mammals as well }\end{array}$ \\
\hline Effects on birds: & Abamectin is practically nontoxic to birds \\
\hline Effects on aquatic organisms: & $\begin{array}{l}\text { Abamectin is highly toxic to fish and } \\
\text { extremely toxic to aquatic invertebrates }\end{array}$ \\
\hline
\end{tabular}

Table 2: The means values of the physico-chemical characteristics of Al-Khadoud channel water (Fathi and Al-Kahtani, 2009)

\begin{tabular}{lc}
\hline Parameters & Concentrations \\
\hline Temperature ${ }^{\circ} \mathrm{C}$ & 18.970 \\
$\mathrm{pH}$ & 7.400 \\
Conductivity $(\mathrm{mS})$ & 3.430 \\
TDS. $\left(\mathrm{gL}^{-1}\right)$ & 2.070 \\
Dissolved $\mathrm{O}_{2}\left(\mathrm{gL}^{-1}\right)$ & 7.490 \\
Alkalinity $\left(\mathrm{m} \mathrm{gL}^{-1}\right)$ & 118.060 \\
Chloride $\left(\mathrm{m} \mathrm{gL}^{-1}\right)$ & 620.870 \\
Nitrate- $\left(\mathrm{m} \mathrm{gL}^{-1}\right)$ & 2.520 \\
Phosphate-P $\left(\mathrm{m} \mathrm{gL}^{-1}\right)$ & 1.300 \\
Sulphate-S $\left(\mathrm{m} \mathrm{gL}^{-1}\right)$ & 293.680 \\
Sodium $\left(\mathrm{mgl}^{-1}\right)$ & 289.250 \\
Potassium $\left(\mathrm{m} \mathrm{gL}^{-1}\right)$ & 24.562 \\
Calcium $\left(\mathrm{m} \mathrm{gL}^{-1}\right)$ & 148.620 \\
Magnesium $\left(\mathrm{m} \mathrm{gL}^{-1}\right)$ & 64.030 \\
COD $\left(\mathrm{m} \mathrm{g}^{-1}\right)$ & 19.020 \\
\hline
\end{tabular}

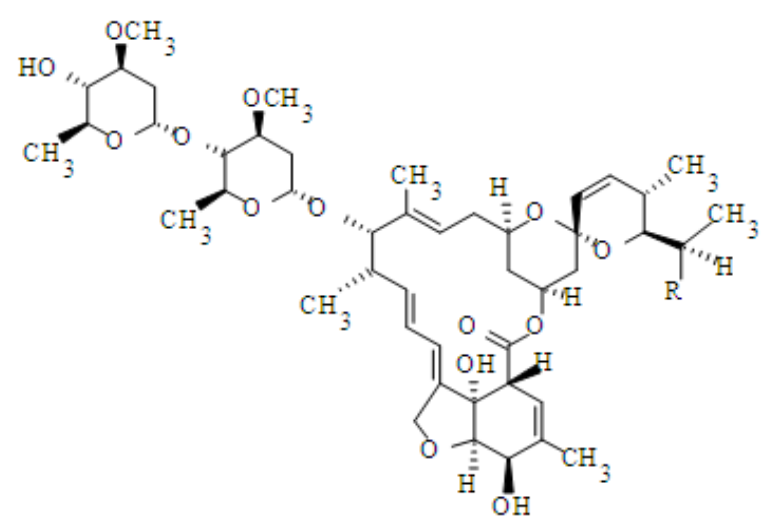

Fig. 1: Structural formula of Abamectin 


\section{RESULTS AND DISCUSSION}

The oxygen consumption and the biochemical constituents of the tilapia fish (Oreochromis niloticus) exposed to sublethal concentration of Abamectin at different exposure periods were observed in the present study. Studies on oxygen consumption form a useful tool in the assessment of toxicant stress on the aquatic organisms and give an index of energy expenditure mechanisms for environmental variation (Sornaraj et al., 2005; Logaswamy and Remia, 2009; Francesco et al., 2008; Franklin et al. 2010).

Toxicants in the environment mainly enter into fish by means of their respiratory system (Tovell et al., 1975). The rate of oxygen consumption $\left(\mathrm{mL} \mathrm{g}^{-1} \mathrm{~h}^{-1}\right)$ of tilapia fish (Oreochromis niloticus) exposed to the sublethal concentrations of Abamectin for different exposure periods are shown in Fig. 2. The data shows that the rate of oxygen consumption was declined during all the exposure periods. Several authors (Rao et al., 2003; Shivakumar and David, 2004; Vutukuru, 2005; Vineetkumar et al., 2008; Shereena et al., 2009; Logaswamy and Remia, 2009) reported that the disturbance in oxidative metabolism leads alteration in completely animal oxygen consumption in different species of fish exposed to pesticides.

Proteins are important organic substances required by organisms in tissue building and play an important role in energy metabolism (Yeragi et al., 2003; Remia et al., 2008; Pang-Hung et al., 2008). The result of the present study showed significant decrease in protein content in the tissues studied (Table 3). The percent decrease was found to be greater in all exposures in liver tissue. The reduction of protein may be due to proteolysis and increased metabolism under toxicant stress (Remia et al., 2008). Dalela et al. (1981) observed a decrease in protein content in Mystus vittatus under pesticide exposure and reported that the depletion of protein may be due to the excretion of proteins by kidney due to kidney failure or impaired protein synthesis as a result of liver disorders. A number of workers have reported decline in protein level of various organs and tissues under toxic stress of various chemicals. Begum and Vijayaraghavan (1996) have reported that the protein content of muscle tissues of fish Clarius botrachus was significantly depleted during $192 \mathrm{~h}$ of dimethoate exposure. Kumar and Saradhamani (2004) observed significant decrease in protein content in all the tissue of the fish Cirrihinus mrigala upon exposure to the pesticide avaunt.

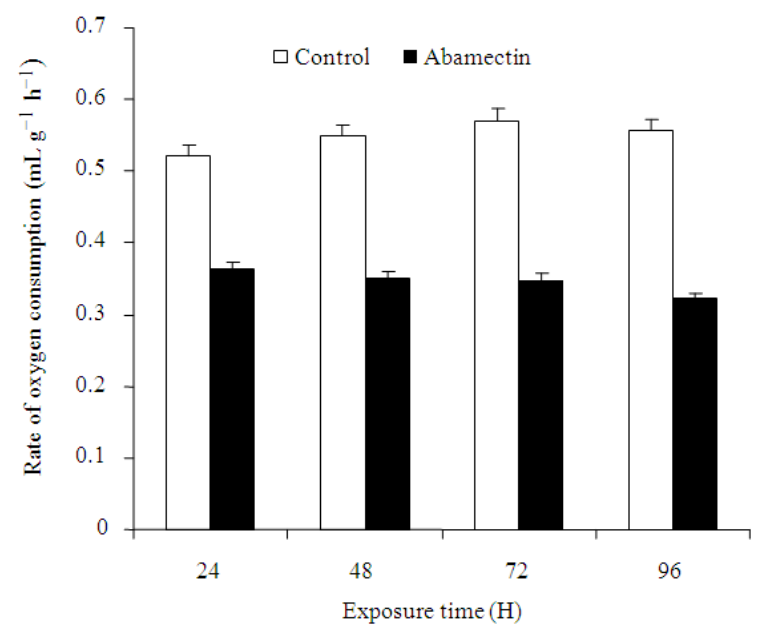

Fig. 2: Rate of oxygen consumption $\left(\mathrm{mL} \mathrm{g} \mathrm{g}^{-1} \mathrm{~h}^{-1}\right)$ of tilapia fish (Oreochromis niloticus) exposed to $20 \mu \mathrm{g} \mathrm{L}^{-1}$ of Abamectin at different times of exposure. Means + SD $(n=4)$

Carbohydrate is an essential component of living cells and sources of energy for animals. The results of the present findings showed a significant decrease in carbohydrate content in all the tissues studied (Table 4). Many workers reported a similar trend of decrease in carbohydrate (Venkatramana et al., 2006; Saradhamani and Selvarani, 2009). On the other hand, some other workers (Witold et al., 2007; Francesco et al., 2008; Logaswamy and Remia, 2009) reported that sublethal concentration of certain organophosphate pesticides caused glycogenolysis, which produced hyperglycemia in the African food fish Tilapia mossambica and the Indian catfish, Heteropneustes fossilis. However, Remia et al. (2008) reported that the elevation of carbohydrates might be due to the stress induced by the insecticides as physiology of organisms with the help of corticosteroids.

Cholesterol is an important normal body constituent used in the structure of cell membranes, synthesis of bile acid and synthesis of steroid hormones. The results presented in Table 5 shows a significant decrease in cholesterol content in the studied tissues of fish Tilapia (Oreochromis niloticus). The decrease was found to be high in gills and less in muscles. Generally, the decreases in cholesterol contents in all tissues were found to be increased with the hours of exposure. The reduced cholesterol level may be due to the inhibition of cholesterol biosynthesis in the liver or due to reduced absorption of dietry cholesterol as reported by Kanagaraj et al. (1993). 
Am. J. Agri. \& Biol. Sci., 6 (1): 62-68, 2011

Table 3: Protein content $\left(\mathrm{mg} \mathrm{g}^{-1}\right)$ in tissues of tilapia fish (Oreochromis niloticus) exposed to $20 \mu \mathrm{g} \mathrm{L}^{-1}$ of Abamectin. Means $\pm \mathrm{SD}(\mathrm{n}=4)$

\begin{tabular}{|c|c|c|c|c|c|}
\hline Exposure & Tissues & Liver & Kidney & Gill & Muscles \\
\hline \multirow[t]{3}{*}{$24 \mathrm{~h}$} & Control & $5.68 \pm 0.06$ & $5.10 \pm 0.03$ & $4.78 \pm 0.08$ & $5.54 \pm 0.11$ \\
\hline & Abamectin & $3.90 \pm 0.05$ & $4.50 \pm 0.05$ & $5.82 \pm 0.55$ & $5.00 \pm 0.09$ \\
\hline & ANOVA & & & $* *$ & ns \\
\hline \multirow[t]{3}{*}{$48 \mathrm{~h}$} & Control & $4.55 \pm 0.11$ & $5.21 \pm 0.05$ & $5.82 \pm 0.03$ & $5.25 \pm 0.06$ \\
\hline & Abamectin & $2.55 \pm 0.09$ & $3.36 \pm 0.08$ & $4.36 \pm 0.13$ & $3.42 \pm 0.05$ \\
\hline & ANOVA & $* * *$ & $* *$ & $* *$ & $*-$ \\
\hline \multirow[t]{3}{*}{$72 \mathrm{~h}$} & Control & $4.54 \pm 0.11$ & $4.88 \pm 0.06$ & $5.80 \pm 0.03$ & $5.23 \pm 0.05$ \\
\hline & Abamectin & $1.90 \pm 0.09$ & $2.98 \pm 0.05$ & $3.49 \pm 0.13$ & $3.11 \pm 0.08$ \\
\hline & ANOVA & $* * *$ & $* * *-$ & $* *-$ & $*$ \\
\hline \multirow[t]{3}{*}{$96 \mathrm{~h}$} & Control & $4.54 \pm 0.11$ & $4.38 \pm 0.06$ & $5.76 \pm 0.03$ & $5.22 \pm 0.05$ \\
\hline & Abamectin & $0.96 \pm 0.09$ & $1.66 \pm 0.05$ & $3.25 \pm 0.13$ & $2.99 \pm 0.08$ \\
\hline & ANOVA & $* * *$ & $* *-$ & $* * *-$ & $*-$ \\
\hline
\end{tabular}

Results of one-way ANOVA indicate *: $\mathrm{p}<0.05 ; * *: \mathrm{p}<0.01 ; * * *: \mathrm{p}<0.001 ; \mathrm{NS}=$ Non significant

Table 4: Carbohydrates content (mg/g) in tissues of tilapia fish (Oreochromis niloticus) exposed to $20 \mu \mathrm{g} \mathrm{L}^{-1}$ of Abamectin. Means \pm SD ( $\mathrm{n}=4$ )

\begin{tabular}{llllll}
\hline Exposure & Tissues & Liver & Kidney & Gill & Muscles \\
\hline $24 \mathrm{~h}$ & Control & $4.21 \pm 0.04$ & $2.56 \pm 0.05$ & $2.02 \pm 0.03$ & $3.56 \pm 0.08$ \\
& Abamectin & $3.05 \pm 0.03$ & $1.64 \pm 0.10$ & $* 32 \pm 0.05$ & $3.05 \pm 0.11$ \\
& ANOVA & $* * *$ & $* * *$ & $1.98 \pm 0.02$ & $*$ \\
$48 \mathrm{~h}$ & Control & $4.44 \pm 0.09$ & $2.57 \pm 0.08$ & $2.26 \pm 0.04$ & $5.55 \pm 0.15$ \\
& Abamectin & $3.02 \pm 0.10$ & $1.87 \pm 0.06$ & $*$ & $3.18 \pm 0.11$ \\
& ANOVA & $* * *$ & $* * *$ & $2.00 \pm 0.04$ & $* *$ \\
$72 \mathrm{~h}$ & Control & $4.61 \pm 0.08$ & $2.50 \pm 0.10$ & $1.34 \pm 0.02$ & $3.54 \pm 0.12$ \\
& Abamectin & $2.38 \pm 0.13$ & $1.67 \pm 0.12$ & $*$ & $3.04 \pm 0.14$ \\
& ANOVA & $* * *$ & $* *$ & $1.96 \pm 0.03$ & $* *$ \\
$96 \mathrm{~h}$ & Control & $4.75 \pm 0.17$ & $2.51 \pm 0.12$ & $1.29 \pm 0.03$ & $3.58 \pm 0.09$ \\
& Abamectin & $2.65 \pm 0.15$ & $1.70 \pm 0.09$ & $*$ & $2.98 \pm 0.08$ \\
& ANOVA & $* * *$ & $* *$ & & $* *$ \\
\hline
\end{tabular}

Results of one-way ANOVA indicate; *: $\mathrm{p}<0.05 ; * *: \mathrm{p}<0.01 ; * * * \mathrm{p}<0.001 ; \mathrm{NS}=$ Non significant

\begin{tabular}{|c|c|c|c|c|c|}
\hline Exposure & Tissues & Liver & Kidney & Gill & Muscles \\
\hline \multirow[t]{3}{*}{$24 \mathrm{~h}$} & Control & $13.08 \pm 0.12$ & $9.94 \pm 0.13$ & $2.11 \pm 0.05$ & $11.98 \pm 0.24$ \\
\hline & Abamectin & $11.14+0.15$ & $9.55+0.11$ & $2.01 \overline{+} 0.01$ & $11.48+0.15$ \\
\hline & ANOVA & $* * *$ & $\mathrm{~ns}$ & $*-$ & \\
\hline \multirow[t]{3}{*}{$48 \mathrm{~h}$} & Control & $13.10 \pm 0.11$ & $9.96 \pm 0.15$ & $2.09 \pm 0.03$ & $11.92 \pm 0.16$ \\
\hline & Abamectin & $9.92 \pm 0.10$ & $9.21 \pm 0.10$ & $1.88 \pm 0.01$ & $10.47 \pm 0.13$ \\
\hline & ANOVA & $* * *$ & $*-$ & $* * *$ & $* *$ \\
\hline \multirow[t]{3}{*}{$72 \mathrm{~h}$} & Control & $13.09 \pm 0.12$ & $9.96 \pm 0.15$ & $2.10 \pm 0.03$ & $10.91 \pm 0.12$ \\
\hline & Abamectin & $9.71 \pm 0.12$ & $8.72 \pm 0.08$ & $1.64 \pm 0.05$ & $9.92 \pm 0.09$ \\
\hline & ANOVA & $* * *$ & $*-$ & $* * *$ & $* *$ \\
\hline \multirow[t]{3}{*}{$96 \mathrm{~h}$} & Control & $13.11 \pm 0.15$ & $9.95 \pm 0.11$ & $2.10 \pm 0.03$ & $11.02 \pm 0.18$ \\
\hline & Abamectin & $9.54 \pm 0.10$ & $8.51 \pm 0.09$ & $1.43 \pm 0.01$ & $9.75 \pm 0.14$ \\
\hline & ANOVA & $* * *$ & $* *$ & $* * *$ & $* * *$ \\
\hline
\end{tabular}

Results of one-way ANOVA indicate; *: $\mathrm{p}<0.05 ; * *: \mathrm{p}<0.01 ; * * *: \mathrm{p}<0.001 ; \mathrm{NS}=$ Non significant

Shakoori et al. (1996) reported that the cholesterol decrease may be due to utilization of fatty deposits instead of glucose for energy purpose. However, Remia et al. (2008) reported that the decline of cholesterol may be due to utilization of fatty dposites instead of glucose for energy purpose.

Various authors studied similar reduction of lipids in various tissues. Ram and Sathyanesan (1984) observed a decreased lipid level in the liver of Channa punctuatus exposed to emisan. Srinivas et al. (1991) has showed decreased lipid content in T. mossambica on exposed to atrazine. Gradual depletion in lipid content of liver and muscle when exposed to Malathion was analysed by Mishra et al. (2004). Arockia and Milton (2006) have showed declining trend of lipid content in the tissues like brain, gill, kidney, liver and muscles upon exposure to carbamate in the fish Oreochromis mossambicus. Saradhamani and Selvarani (2009) showed significant decrease in cholesterol content in the tissues of the freshwater fish, Tilapia mossambica exposed to metribuzin. 


\section{CONCLUSION}

A toxicant induce its effect at cellular or even at molecular level, but ultimately cause physiological and biochemical alterations. The results of the present study clearly indicate the toxic nature of the insecticide Abamectin on the oxygen consumption and the biochemical constituents of the tilapia fish (Oreochromis niloticus). The changes in proteins, carbohydrates and lipid in the insecticide Abamectin treated fishes will naturally affect the nutritive value of these animals and all the metabolites studied are found to be sensitive changes in the normal indictors, which reflect changes in the normal activities of various functional systems. It is therefore necessary to focus attention on changes in biochemical composition of aquatic organisms, which are under pollutant threat.

\section{ACKNOWLEDGEMENT}

We thank the Dean of Deanship of Scientific Research, King Faisal University and the Deanship members for financial support (Grant No: 10085).

\section{REFERENCES}

Alkhail, A.R., A.I. Askar, L.K. Younis, K.S. El-Gendy and M.M. Abbas, 2004. Risk assessment of tributyltin oxide in aquatic environment: A. toxicity and sublethal effects on brain AChE and gill ATPases activity of tilapia fish, Oreochromis niloticus. Pak. J. Biol. Sci., 7: 1117-1120.

Anandkumar, S., 1988. Effect of endosulphan on oxygen consumption of Lepidocepalicthys thermalis (bleeker) comp. Phys. Ecol., 23: 191-194.

Arockia, J.J. and J.M.C. Mitton, 2006. Effect of carbamate pesticide lannate (methomy1) on the biochemical components of the freshwater cichlid Oreochromis mossambicus (Peters). Ind. J. Environ Ecoplan., 12: 263-268.

Ayoola S.O., 2008. Toxicity of glyphosate herbicide on Nile tilapia (Oreochromis niloticus) juvenile. Afr. J. Agric. Res., 3 (12): 825-834

Begum, G. and S. Vijayaraghavan, 1996, Alterations in protein metabolism of Muscle Tissue in the fish Clarias batrachus (Linn) by commercial grade dimethoate. Bull. Environ. Contam. Toxicol., 57: 223-228.

Bela, Z. and R. Prasad, 2008. Impact of pollution on fresh and marine water resources. J. Poll. Res., 273: 461-466.
Dalela, R.C., S. Rani, V. Kumar and S.R. Verma, 1981. In vivo haematological alterations in a fresh water teleost Mystus vittatus following subacute exposure to pesticide and their combinations. J. Environ. Biol., 2: 79-86.

Fathi A. and M.A. Al-Kahtani, 2009. Water quality and planktonic communities in al-khadoud spring, Al-Hassa, Saudi Arabia. Am. J. Environ. Sci., 5: 434-443.

Fathi, A.A. and M.A. Al-Fredan, 2007. Effect of the insecticide Abamectin on the metabolic activity of Chlorella vulgaris Beyerinck Egyptian J. Phycol., 8: $1-12$.

Finney, D.J., 1971. Probit Analysis. 3rd Edn., Cambridge University Press, London, pp: 20.

Francesco P., I. Francesca, G. S. Umile, C. Giuseppe, C. Manuela and P. Nevio, 2008. Polymer in Agriculture: a Review. Am. J. Agri. Biol. Sci., 3: 299-314.

Franklin R. K., H. S. Loo and H. A. Osumanu, 2010. Incorporation of Bentazone with Exserohilum rostratum for Controlling Cyperus iria. Am. J. Agri. Biol. Sci., 5: 210-214.

Hedge, J.E. and B.T. Hofreiter, 1962. Determination of Total Carbohydrate by Anthrone Reagent. In: Carbohydrate Chemistry, Whistler, R.L. and J.N. Be Miller (Eds.). Academic Press, New York.

Kamel, A.A., S. Al-Dosary, S. Ibrahim and A.M.A. Asif, 2007. Degradation of the acaricides abamectin, flufenoxuron and amitraz on Saudi Arabian dates. Food Chem., 10: 1590-1593.

Kanagaraj, M.K., M. Ramesh, K. Sivakumari and R. Manavalaramanujam, 1993. Impact of acid pollution on the serum haemolymph cholesterol of the crab, Paratelphusa hydrodromous. J. Ecotoxicol. Environ. Monit., 3: 99-102.

Khan, M.Z. and C.P.L. Francis, 2005. Adverse effects of pesticides and related chemicals on enzyme and hormone systems of fish, amphibians and reptiles. Proc. Pakistan AcMad. Z Sahceie, 42: 15-323.

Kumar, K. and N. Saradhamani, 2004. Effect of insecticide, avaunt, on glycogen content of the fresh water fish Cirrhinus mrigala. Nature Environ. Pollut. Technol., 3: 515-518.

Logaswamy, S. and K.M. Remia, 2009. Impact of Cypermethrin and Ekalux on respiratory and some biochemical activities of a fresh water fish, Tilapia Mossambica. Current Biotica, 3: 65-73. 
Lowry, O.H, N.J. Rosenbrough, A.L. and R. J. Randall, 1951. Protein measurements with folin phenol reagent. J. Biol. Chem., 193: 265-267.

Maruthanayagam, C. and G. Sharmila, 2004. Haematobiochemical variations induced by the pesticide, Monocrotophos in Cyprinus carpio during the exposure and recovery periods. Nat. Environ. Poll. Tech., 3: 491-494.

Mishra, S.K., J. Padhi and L. Sahoo, 2004. Effect of malathion on lipid content of liver and muscles of Anabas testudineus. J. Appl. Zool. Res., 15: 81-82.

Pang-Hung ,Y., S. Jian, R. Amartalingam and J.B. Choon-Fah 2008. Boric Acid Levels in Fresh Noodles and Fish Ball. Am. J. Agril. Biol. Sci., 3: 476-481.

Patnaik, L., 2010. Biochemical alterations induced by sevin in clarias batrachus. Asian J. Exp. Biol. Sci., 1: 124-127.

Prado, R., C. Rioboo, C. Herrero and A. Cid, 2009. The herbicide paraquat induces alterations in the elemental and biochemical composition of nontarget microalgal species. Chemosphere, 76: 1440-1444. DOI: 10.1016/j.chemosphere. 2009. 06.003

Ram, R.H. and A.G. Sathyanesan, 1984. Mercuric chloride induced changes in the protein lipid and cholesterol levels of the liver and ovary of fish, Channa punctatus. Environ. Ecol., 2: 113-117.

Rao, J.V., C.H.S. Rani, P. Kavitha, R.N. Rao and S.S. Madhavendra, 2003. Toxicity of chlorpyrifos to the fish, Oreochromis mossambicus. Bull. Environ. Contam. Toxicol., 70: 985-992. DOI: 10.1007/s00128-003-0079-0

Remia, K.M., S. Logaswamy, K. Logankumar and D. Rajmohan, 2008. Effect of an insecticides (Monocrotophos) on some biochemical constituents of the fish Tilipia Mossambica. Poll. Res., 27: 523-526.

Richmond, W., 1973. Preparation and properties of a cholesterol oxidase from Nocardia sp. and its application to the enzymatic assay of total cholesterol in serum. Clin. Chem., 19: 1350-1356.

Saradhamani, N. and B.J. Selvarani, 2009. A study on the effect of herbicide metribuzin on the biochemical constituents of the freshwater fish, Tilapia mossambica Peters (Pisces: Cichlidae). Curr. Biotica, 3: 220-231.

Shakoori, A.R., A.L. Mughal and M. Iqbal, 1996. Effect of sublethal doses of fenvalarate (A synthetic pyrethroid) administered continuously for 4 weeks on the blood, liver, muscles of freshwater fish. Etenopharyngodon idella, Bull. Environ. Contam. Toxicol., 57: 487-499.
Shereenạ, K.M., S. Logaswamy and P. Sunitha, 2009. Effect of an organo phosphorous pesticides (Dimethoate) on oxygen consumption of the fish Tilapia Mossambica. Recent Res. Sci. Technol., 1: 4-7.

Shivakumar, R. and M. David, 2004. Toxicity of endosulfan to the freshwater fish, Cyprinus carpio. Ind. J. Ecol., 31: 27-29.

Sornaraj, I.R., A.J. Ranjitsingh, A., A. Pushparaj and G. Ramathilagam, 2005. Pesticidal stress influenced respiratory alterations in the fresh water fish, Mystus vittatus. Indian. J. Environ. Ecoplan., 10: 803-806.

Srinivas, T., T.A.V. Prasad, G.M.D. Rafi and D.C. Reddy, 1991. Effect of atrazine on some aspects of lipid metabolism in freshwater fish. Biol. Inter., 23: 603-609.

Tatjana, T. and K. Nevenka, 2006. Abamectin in the aquatic environment. Ecotoxicology, 15: 495-502. PMID: 16741677

Tilak, K.S., K. Veeraiah and G.V. Ramanakumari, 2001, Toxicity and effect of chloropyriphos to the freshwater fish Labeo rohita (Hamilton) Rol. Res., 20: 438-445.

Tovell, P.W.A., D. Howes and C.S. Newsome, 1975. Absorption, metabolism and excretion by gold fish of the anionic detergent, Sodium lauryl sulphate. Toxicol., 6: 17-29.

Venkateswara, J.R., 2006. Toxic effects of novel organophosphorus insecticide (RPR-V) on certain biochemical parameters of euryhaline Wsh, Oreochromis mossambicus. Pesticide Biochem. Physiol., 86: 78-84.

Venkatramana, G.V., P.N. Sandhya Rani and P.S. Moorthy, 2006. Impact of Malathion on the biochemical parameters of gobiid fish, Glossogobius giuris (Ham). J. Environ. Biol., 27: 119-122.

Vineetkumar, K. Patil and M. David, 2008. Behaviour and respiratory dysfunction as an index of malathion toxicity in the freshwater fish, labeo rohita (Hamilton). Turkish J. Fisheries Aquatic Sci., 8: 233-237.

Vutukuru, S.S., 2005. Acute effects of hexavalent chromium on survival, oxygen consumption. Hematological parameters and some biochemical profiles of the Indian major carp, labeo rohita. Int. J. Environ. Res. Public Health, 2: 456-462.

Welsh, J.H. and R. I. Smith, 1960. Laboratary Exercise in Invertebrate Physiology, Minneapolis, Burgess Publishing Company, 159-160. 
Witold, J., S. Marek, K. Robert, C. Józefa, 2007. Effect of Fat-Mineral Preparation From Fish Oil on Fatty Acid Content on Cow Milk. Am. J. Agril. Biol. Sci., 2: 276-283.
Yeragi, S.G., A.M. Ranaand V.A. Koli, 2003. Effect of pesticide on protein metabolism of mudskipper, Boleophtalmus dussumieri. J. Ecotoxicol. Environ. Monit., 13: 211-214. 